\title{
Early sex-dependent differences in response to environmental stress
}

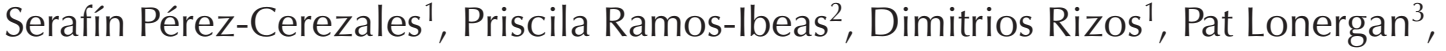 \\ Pablo Bermejo-Alvarez ${ }^{1}$ and Alfonso Gutiérrez-Adán ${ }^{1}$ \\ ${ }^{1}$ Departamento de Reproducción Animal, INIA, Madrid, Spain, ${ }^{2}$ School of Biosciences, University of Nottingham, \\ Loughborough, UK and ${ }^{3}$ School of Agriculture and Food Science, University College Dublin, Dublin, Ireland
}

Correspondence should be addressed to A Gutiérrez-Adán; Email: agutierr@inia.es

\begin{abstract}
Developmental plasticity enables the appearance of long-term effects in offspring caused by exposure to environmental stressors during embryonic and foetal life. These long-term effects can be traced to pre- and post-implantation development, and in both cases, the effects are usually sex specific. During preimplantation development, male and female embryos exhibit an extensive transcriptional dimorphism mainly driven by incomplete $\mathrm{X}$ chromosome inactivation. These early developmental stages are crucial for the establishment of epigenetic marks that will be conserved throughout development, making it a particularly susceptible period for the appearance of long-term epigenetic-based phenotypes. Later in development, gonadal formation generates hormonal differences between the sexes, and male and female placentae exhibit different responses to environmental stressors. The maternal environment, including hormones and environmental insults during pregnancy, contributes to sex-specific placental development that controls genetic and epigenetic programming during foetal development, regulating sex-specific differences, including sex-specific epigenetic responses to environmental hazards, leading to long-term effects. This review summarizes several human and animal studies examining sex-specific responses to environmental stressors during both the periconception period (caused by differences in sex chromosome dosage) and placental development (caused by both sex chromosomes and hormones). The identification of relevant sex-dependent trajectories caused by sex chromosomes and/or sex hormones is essential to define diagnostic markers and prevention/intervention protocols.

Reproduction (2018) 155 R39-R51
\end{abstract}

\section{Introduction}

Thefoetal origins of adult disease hypothesis (so-called 'Barker hypothesis') (Barker \& Osmond 1986) proposes that undernutrition during gestation is, in part, responsible for adult cardiac and metabolic disorders due to foetal programming in utero that permanently shapes the body's structure, function and metabolism and contributes to susceptibility to adult diseases. This hypothesis has led to a wider theory, known as the 'Developmental Origins of Health and Disease (DOHaD)', which is based on developmental plasticity (the ability of the genotype to produce different phenotypes in response to different environments) and the concept of evolutionary mismatch (evolved traits that were once advantageous but became maladaptive due to changes in the environment). There are several critical stages when development is malleable (periconception, pregnancy and early postnatal life) and exhibits an enhanced plasticity that enables the organism to fine-tune epigenetic control of gene expression in accordance with environmental cues. During these periods, the embryo can adapt to novel conditions and diverse environments, reprograming developmental trajectories in order to confer the best chance of survival and reproductive success. However, these adaptive changes can conflict with the postnatal environment and impair adult heath. The time of maximal plasticity appears during periconception, as plasticity is reduced progressively as foetal development proceeds (Fig. 1). There are three key periods (embryonic, foetal, lactation) during which environmental stress exerts a greater effect. Sexual dimorphism in the $\mathrm{DOHaD}$ context of health and disease is a phenomenon among a variety of species, but it generally occurs in most common noncommunicable diseases (NCDs), including cardiovascular disease, metabolic diseases, hypertension, neurological disorders and cancer (Junien et al. 2012, Kalisch-Smith et al. 2017). NCDs continue to be the leading cause of deaths worldwide and were responsible for 38 million of the world's 56 million deaths in 2012, and WHO predicts a $17 \%$ increase in NCDs during the next decade (Mendis et al. 2015). The concept of DOHaD represents an important approach to the understanding and prevention of the alarming and increasing incidence of NCD, as recent studies of variable regions of neonatal methylome 


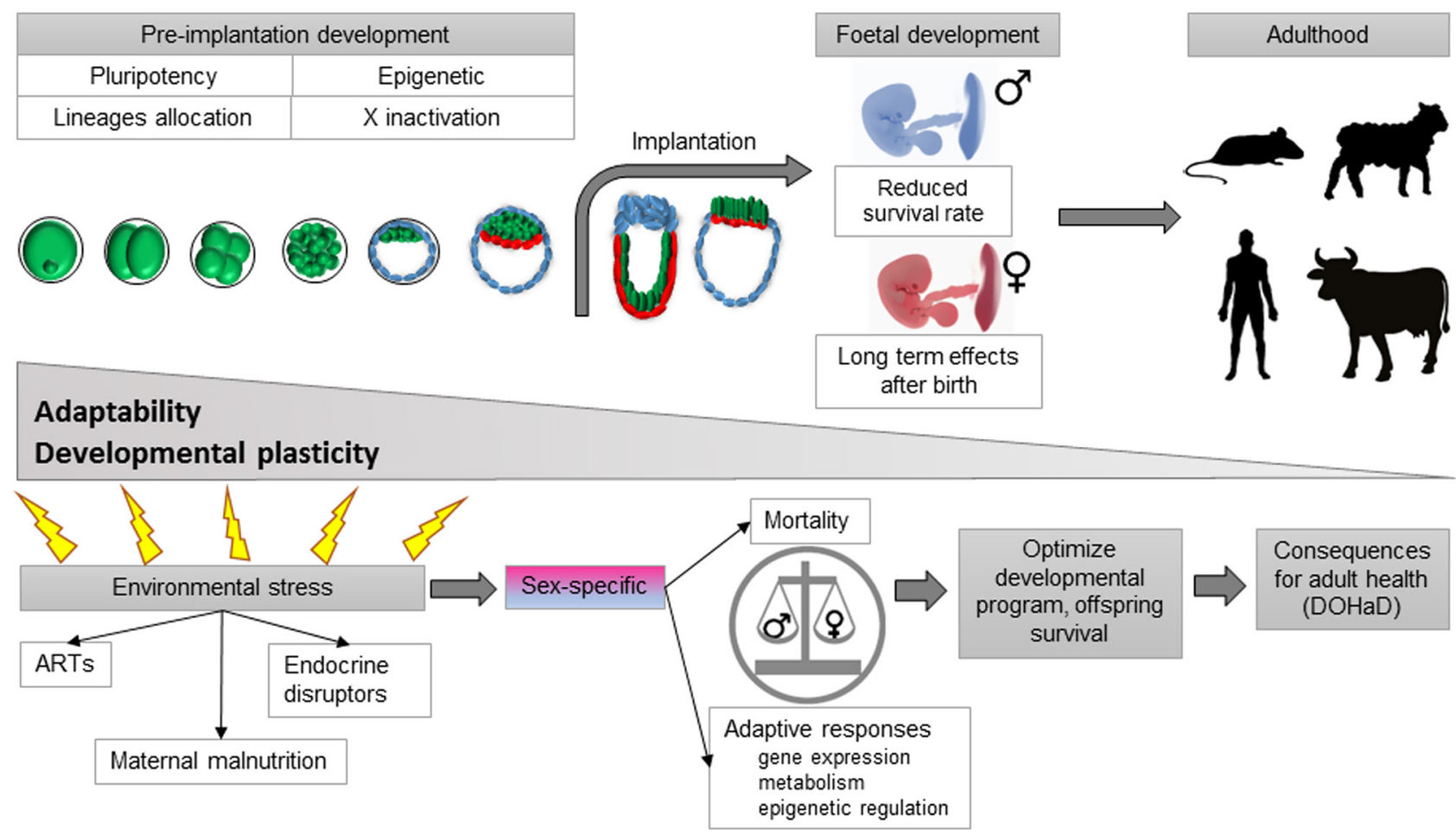

Figure 1 Pre- and peri-implantation embryo adaptations to environmental stress. Comparative pre- and peri-implantation embryo development in mammals. Critical events taking place during this developmental window (pluripotency emergence, epigenetic reprogramming, lineage allocation and $\mathrm{X}$ chromosome inactivation) render the embryo especially sensitive to environmental stress. Such embryos and the resulting foetus respond to stressors by sex-specific mortality or by adaptive responses in order to optimize their developmental program and offspring survival. The adaptability due to developmental plasticity (the ability of the genotype to produce different phenotypes in response to different environments) decrease throughout embryo and foetal development until early postnatal life. Later in adult life, this adaptability disappears and only the brain maintains a certain degree of plasticity. The female placenta (in pink), due to its higher adaptability, buffers more efficiently the impact of endogenous and exogenous stressors on the foetus and it is less compromised than male foetus (in blue) under similar stress conditions. However, compensatory mechanisms can compromise adult health according to the developmental origins of adult health and disease $(\mathrm{DOH} a \mathrm{D})$.

demonstrate that the interaction of genotype with the uterine environment accounts for $75 \%$ of unexplained variability (Teh et al. 2014).

In the context of DOHaD, the epigenetic marks that respond to the environment register the effects during the development of a specific sex (Heijmans et al. 2009). Environmental epigenetics investigates environmental factors that impact on the organism to modulate the expression of genes across the life course. The two most prominent stages are the perimplantation period and the period of foetal development, where epigenetic alterations may affect not only birth outcomes but also lifelong health. Some early environmental events such as stress, nutrition, behavior and environmental pollutants may disturb the precisely timed processes that sculpt the embryo and foetus in a sex-dependent manner and thus influence its health in later life (Attig et al. 2010). We have reported that sex differences in embryonic metabolism, gene expression and epigenetics start from the blastocyst stage (Gutierrez-Adan et al. 2000, 2006, Bermejo-Alvarez et al. 2008), and these differences are caused by extra gonadal and dosage effects of genes encoded on sex chromosomes. Sex has been proposed as a major factor determining the type and severity of the long-term effects originating during the preimplantation period (Bermejo-Alvarez et al. 2011a). Preimplantation developmental plasticity has evolved in order to offer the best chances of survival under changing environments. Conversely, environmental conditions experienced in early life can dramatically influence neonatal and adult biology, which may result in detrimental long-term effects (Laguna-Barraza et al. 2012). There are many human and animal studies demonstrating sexual differences in response to various developmental insults during periconception (Fleming et al. 2015a) and pregnancy (Sundrani et al. 2017) and demonstrating sexual differences in response to various developmental insults during pregnancy (Sundrani et al. 2017). However, there is a gap in knowledge of the mechanism(s) mediating environmental and maternal programing of preimplantation development. For example, how can environmental conditions during the preimplantation period have a long-term effect? How does the early embryo sense its environment and how 
are morphogenesis, metabolism, genetic and epigenetic alterations induced? What are the sex-specific differences and how are they maintained, erased or gave rise to new ones?

\section{Preimplantation embryo development, a crucial period for the appearance of sex-specific long- term effects}

Sexdifferences in geneexpression emergewith embryonic genome activation, and they are dynamic throughout the lifespan. Although some authors have suggested that transcriptional sex differences are higher in adult tissues compared with preimplantation embryos at the 8-cell stage (Lowe et al. 2015), no transcriptional analysis in adult tissues has reported the massive transcriptional sex differences observed in both mouse (Kobayashi et al. 2006) and bovine (Bermejo-Alvarez et al. 2010) blastocysts. Preimplantation embryo development constitutes a critical period for the establishment of epigenetic marks, being one of the two unique moments during the lifespan where genome-wide demethylation occurs (Seisenberger et al. 2012). During these early developmental stages, key epigenetic processes, such as $\mathrm{X}$ chromosome inactivation $(\mathrm{XCl})$ or initial telomere lengthening, take place (de Frutos et al. 2016).

Table 1 Different studies showing sex-specific effects of environmental alterations during preimplantation development, either in vivo through maternal stress or in vitro by assisted reproductive technologies (ARTs).

\begin{tabular}{|c|c|c|c|c|c|}
\hline & \multirow[b]{2}{*}{ Treatment } & \multicolumn{3}{|c|}{ Effect } & \multirow[b]{2}{*}{ Reference } \\
\hline & & Both sexes & Females only & Males only & \\
\hline \multicolumn{6}{|l|}{ Maternal stress } \\
\hline Mouse & $\begin{array}{l}\text { Heat stress-induced } \\
\text { oxidative damage in } \\
\text { pregnant mice and } \\
\text { in vitro cultured } \\
\text { embryos }\end{array}$ & & & Increased embryo loss & $\begin{array}{l}\text { Perez-Crespo et al. } \\
\text { (2005) }\end{array}$ \\
\hline Sheep & $\begin{array}{l}\text { Restriction of B } \\
\text { vitamins and } \\
\text { methionine in } \\
\text { maternal diet }\end{array}$ & $\begin{array}{l}\text { Obesity, insulin } \\
\text { resistance, elevated } \\
\text { blood pressure, DNA } \\
\text { methylation alterations }\end{array}$ & & More severe phenotype & Sinclair et al. (2007) \\
\hline Mouse, rat & $\begin{array}{l}\text { Low-protein maternal } \\
\text { diet }\end{array}$ & $\begin{array}{l}\text { Cardiovascular, } \\
\text { metabolic and } \\
\text { behavioural alterations }\end{array}$ & More severe phenotype & & $\begin{array}{l}\text { Fleming et al. } \\
\quad(2015 b)\end{array}$ \\
\hline \multicolumn{6}{|c|}{ Assisted reproductive technologies } \\
\hline Bovine & $\begin{array}{l}\text { High glucose } \\
\text { environment in vitro }\end{array}$ & & Increased embryo loss & & $\begin{array}{l}\text { Gutierrez-Adan et al. } \\
\text { (2001) }\end{array}$ \\
\hline Mouse, bovine & $\begin{array}{l}\text { High glucose } \\
\text { environment in vitro }\end{array}$ & Increased apoptosis & $\begin{array}{l}\text { Increased survival and } \\
\text { implantation }\end{array}$ & & Jimenez et al. (2003) \\
\hline Mouse & $\begin{array}{l}\text { In vitro culture with } \\
\text { serum }\end{array}$ & $\begin{array}{l}\text { Altered behavior, } \\
\text { imprinted genes } \\
\text { expression }\end{array}$ & $\begin{array}{l}\text { Increased body weight, } \\
\text { liver steatosis }\end{array}$ & Hyperactivity, anxiety & $\begin{array}{l}\text { Fernandez-Gonzalez } \\
\quad \text { et al. (2004) }\end{array}$ \\
\hline Mouse & $\begin{array}{l}\text { In vitro culture without } \\
\mathrm{CSH} 2\end{array}$ & $\begin{array}{l}\text { Restricted foetal growth, } \\
\text { increased body weight } \\
\text { and adiposity, placenta } \\
\text { alterations }\end{array}$ & & $\begin{array}{l}\text { Increased body weight } \\
\text { and adiposity, } \\
\text { decreased brain size }\end{array}$ & Sjoblom et al. (2005) \\
\hline Mouse & $\begin{array}{l}\text { ICSI with DNA- } \\
\text { fragmented sperm }\end{array}$ & $\begin{array}{l}\text { Reduced embryo } \\
\text { development and } \\
\text { offspring, altered gene } \\
\text { transcription and } \\
\text { methylation, } \\
\text { increased mortality, } \\
\text { premature aging }\end{array}$ & $\begin{array}{l}\text { Behavioural alterations, } \\
\text { higher body weight } \\
\text { and organ size, } \\
\text { increased tumor } \\
\text { incidence }\end{array}$ & $\begin{array}{l}\text { Delayed active } \\
\text { demethylation of } \\
\text { male pronucleus }\end{array}$ & $\begin{array}{l}\text { Fernandez-Gonzalez } \\
\text { et al. (2008) }\end{array}$ \\
\hline Mouse & IVF, ISCI, SCNT & Increased body weight & $\begin{array}{l}\text { Altered glucose } \\
\text { clearance, higher } \\
\text { body weight and } \\
\text { adiposity }\end{array}$ & & Scott et al. (2010) \\
\hline Mouse & IVF & & & $\begin{array}{l}\text { Increased body weight } \\
\text { and heart size, } \\
\text { glucose intolerance }\end{array}$ & $\begin{array}{l}\text { Donjacour et al. } \\
\text { (2014) }\end{array}$ \\
\hline Mouse & IVF & $\begin{array}{l}\text { Sex-specific differences } \\
\text { in sterol metabolism, } \\
\text { redox state, } \\
\text { mobilization and } \\
\text { oxidation of fatty acids }\end{array}$ & $\begin{array}{l}\text { Increased fat } \\
\text { accumulation, } \\
\text { altered fat metabolite } \\
\text { composition }\end{array}$ & $\begin{array}{l}\text { Altered liver metabolite } \\
\text { composition }\end{array}$ & Feuer et al. (2014) \\
\hline Mouse & IVF & & $\begin{array}{l}\text { Increased apoptosis } \\
\text { and pregnancy loss }\end{array}$ & $\begin{array}{l}\text { Placental overgrowth, } \\
\text { postnatal overgrowth }\end{array}$ & Tan et al. (2016) \\
\hline
\end{tabular}


These dynamic changes of the epigenetic landscape exert a double impact on sex-specific long-term effects. On the one hand, incomplete $\mathrm{XCl}$ results in sex-unbalanced expression of X-linked genes, leading not only to an upregulation of these genes in females, but also to a genome-wide sex-specific transcriptional regulation in autosomal genes. On the other hand, the dynamic changes in the epigenome make this period particularly vulnerable to the appearance of aberrant epigenetic marks. In this perspective, the combination of the greatest transcriptional sexual dimorphism with the most susceptible period for the appearance of stable epigenetic alterations results in the most relevant period for the generation of sex-specific responses to stressors, leading to sex-specific phenotypic consequences for the offspring (Table 1).

\section{Sex chromosomes drive sex differences in the absence of gonads}

In the absence of gonads, and therefore without any sexspecific hormonal bias, sexual dimorphism during the preimplantation period relies solely on the differences in sex chromosome dosage. Thus, Y-linked genes will only be expressed in males, whereas $\mathrm{X}$-linked genes will be upregulated in females if $\mathrm{XCl}$ is not accomplished, which is actually the case for most preimplantation embryos (Bermejo-Alvarez et al. 2012a). The dynamics and mechanism leading to $\mathrm{XCl}$ during preimplantation development have been the subject of debate over the last 10 years. Initial experiments conducted in the mouse observed that $\mathrm{XCl}$ was effectively accomplished in an imprinted manner by the blastocyst stage, experiencing a reactivation exclusively in the inner cell mass (Kay et al. 1994). This situation was thought to be comparable to other mammalian species, but transcriptional studies in bovine blastocysts refuted this notion, as most $X$-linked genes were upregulated in female blastocysts compared to their male counterparts (Bermejo-Alvarez et al. 2010). This situation was also observed in rabbit and human blastocysts by conducting in situ hybridization (ISH) studies (Okamoto et al. 2011), and in pigs, by transcriptional (Park et al. 2012) and methylation analyses (Hwang et al. 2015), so the mouse model was deemed to be more an exception than a rule for $\mathrm{XCl}$ dynamics (Bermejo-Alvarez et al. 2012a). Indeed, bovine (Bermejo-Alvarez et al. 2010) and rabbit (Okamoto et al. 2011) embryos achieve extensive $\mathrm{XCl}$ later, around the time of gastrulation, which opens a large window when the upregulation of $X$-linked genes in female embryos occurs and provides a molecular basis for the appearance of sex-specific phenotypes. In the case of human embryos, a recent study using single-cell RNA-Seq has observed that before $\mathrm{XCl}$ is accomplished, biallelic expression of XIST in female embryos causes progressive dampening of $X$ chromosome expression (Petropoulos et al. 2016), an unexpected phenomenon that urges the revisiting of $\mathrm{XCl}$ dynamics in human stem cells (Lamas-Toranzo et al. 2017). This progressive downregulation, occurring in both X-chromosomes, gradually compensates for the differences in the expression of $X$-linked genes between the sexes, but it still leaves a large period of significant transcriptional sexual dimorphism - almost all preimplantation development, in fact - which may result in sex-specific long-term effects.

\section{Sex chromosomes regulate autosomes, amplifying transcriptional sex differences}

Sex-biased expression of $\mathrm{Y}$ - and $\mathrm{X}$-linked genes is not the only transcriptional difference between male and female preimplantation embryos. Extensive transcriptional sex differences, affecting not only genes located on sex chromosomes but also many autosomal genes has been uncovered in preimplantation embryos by genomewide transcriptional analyses in mice (Kobayashi et al. 2006) and, especially, cattle blastocysts, where almost one-third of the genes actively expressed showed transcriptional sex differences (Bermejo-Alvarez et al. 2010). The wider extent of transcriptional sex differences in bovine blastocysts compared with murine can be explained as a consequence of the incomplete $\mathrm{XCl}$ status in cattle compared to mice. In agreement with this notion, transcriptional sex differences are dramatically reduced in more advanced stages of bovine embryogenesis, such as in Day 14 (Bermejo-Alvarez et al. 2011b) or Day 19 (Forde et al. 2016) elongated conceptuses, once $\mathrm{XCl}$ has been mostly accomplished. Besides, gene co-expression networks analysis between $X$-linked genes upregulated in bovine female blastocysts and autosomal genes showing transcriptional sexdependent differences has identified a major module of autosomal genes for which sex differences are likely driven by the X genes (Itoh \& Arnold 2014). Effects of $X$ chromosome on autosomal transcriptional regulation are also evident in sex-reversed mouse models: over 1000 autosomal genes were found differentially expressed between $X Y$ and $X X$ males or $X X$ and $X Y$ females (Wijchers et al. 2010).

The mechanisms by which upregulated X-linked genes affect the expression of autosomal genes remain to be determined; however, the presence of different genes encoding for chromatin modifiers on the $X$ chromosome provides a plausible explanation. Both KDM5C (H3K4 demethylase, also known as JARID1C) and UTX (H3K27 demethylase, also known as KDM6A) are $\mathrm{X}$-linked genes, and the chromatin marks they regulate are particularly relevant for preimplantation development. H3K4me3 is involved in transcriptional activation, whereas $\mathrm{H} 3 \mathrm{~K} 27 \mathrm{me} 3$ is associated with transcriptional repression. Both opposing marks are 
present in early blastomeres on the promoters for genes involved in early cell differentiation. Bivalent domains keep these genes, including Sox2, Lifr, Nanog, Cdx2, Eomes and Tbpa, poised for activation, occurring once they lose the repressive H3K27me3 mark (Dahl et al. 2010). Given the sex differences in the transcription of key regulators of these bivalent domains, the effect of different stressors on the differentiation processes occurring during preimplantation development may also be sex specific. This effect may depend on the stressor, as although high glucose exposure does not have a sexdependent effect on inner cell mass and trophectoderm cell counts in mouse blastocysts (Bermejo-Alvarez et al. 2012b), human male blastocysts have been reported to exhibit a better quality trophectoderm (TE) than female when cultured in vitro (Ebner et al. 2016), which may have short-term consequences on implantation or longterm consequences on placental development.

\section{Developmental consequences of preimplantation transcriptional sex differences}

Genes which transcription is sex dependent exert different functions which may determine a sex-specific response to a given stressor (Fig. 1). Metabolic differences between male and female embryos could determine a differential response to nutritional stress that may result in sex-specific early embryonic death or long-term effects. Glucose metabolism was initially reported to be different between sexes based on the upregulation of glucose-6-phosphate dehydrogenase (G6PD) in bovine (Gutierrez-Adan et al. 2000, Wrenzycki et al. 2002) and human (Taylor et al. 2001) female blastocysts, and on the overexpression of the autosomal SLC2A3 in bovine male blastocysts (Morton et al. 2007). However, gene ontology analysis of global transcriptional differences between male and female bovine blastocysts did not highlight glucose metabolism as a sexually dimorphic pathway (Bermejo-Alvarez et al. 2010). The specific transcriptional analysis of genes involved in either anaerobic glycolysis or the pentose phosphate pathway do not show a clear sex bias (Bermejo-Alvarez et al. 2011a), and the transcriptional response of bovine blastocysts to the presence of glucose was found to be unrelated to sex (Cagnone et al. 2011), all in agreement with the overall inconsistent reports regarding glucosemediated sex biases (reviewed in Bermejo-Alvarez et al. $2012 b$ ). On the other hand, gene ontology analysis of bovine blastocysts highlighted mitochondria and protein translation, proteolysis and protein transport as sex-dependent pathways (Bermejo-Alvarez et al. 2010), which correlates with the differences between sexes in mtDNA content (Bermejo-Alvarez et al. 2008) and amino acid metabolism (Sturmey et al. 2010) as previously reported. Sex-specific differences in these and other pathways provide a molecular basis for the appearance of a sex-specific response to nutritional stressors and may also be used for non-invasive embryo sexing methods (Sturmey et al. 2010, Gomez et al. 2016).

Other pathways reported to exhibit sex differences include those related to apoptosis and embryo-maternal communication. The $\mathrm{X}$-linked inhibitor of apoptosis $X I A P$ is, as are most $\mathrm{X}$-linked genes, upregulated in female embryos (Gutierrez-Adan et al. 2001), which is consistent with the notion that male embryos are more sensitive to oxidative-induced heat stress (Perez-Crespo et al. 2005). Nevertheless, under normal in vitro culture conditions, female bovine blastocysts seem to be more prone to apoptosis (Ghys et al. 2016). The differential apoptotic rates between sexes under different stressors may result in one sex being more susceptible than the other to blastomere loss, which may have consequences for subsequent development. Furthermore, sex differences may also affect embryo-maternal signaling, which is essential for proper late embryonic development and implantation. Interferon tau, IFNT, a major embryoderived signaling molecule for pregnancy recognition in ruminants, and PGRMC1, a progesterone receptor, are upregulated in female bovine embryos (Larson et al. 2001, Arias-Alvarez et al. 2011, Bermejo-Alvarez et al. $2011 b$ ), and the embryokine CSF2 exerts a sex-specific response (Dobbs et al. 2014).

Finally, transcriptional differences between sexes may directly affect epigenetics in a sexually dimorphic manner, thereby exerting a direct impact on the appearance of sex-specific long-term developmental consequences. Apart from the X-linked genes already discussed, autosomal genes including both de novo DNA methyltransferases (DNMT3A and DNMT3B) and two genes related with histone methylation (HMT1 and ILF3) are upregulated in male bovine blastocysts compared to their female counterparts (BermejoAlvarez et al. 2008). These transcriptional differences are reflected in the methylation levels of specific sequences such as the repetitive sequence VNTR (Bermejo-Alvarez et al. 2008) and one differentially methylated region (DMR) in the imprinted gene IGF2 (Gebert et al. 2009), both being hypomethylated in female bovine blastocysts compared to males. Similar methylation differences are observed in closely related biological systems such as murine embryonic stem cells (ES), where XX cell lines are hypomethylated compared to XY lines (Zvetkova et al. 2005). Sexual dimorphism in histone modification may also arise, as differences in histone modifications methyltransferases of $\mathrm{H} 3 \mathrm{~K} 4 \mathrm{me} 3, \mathrm{H} 3 \mathrm{~K} 27 \mathrm{me} 3$ and $\mathrm{H} 3 \mathrm{~K} 9 \mathrm{me} 3$, as well as DNA methyltransferases, have been observed in male and female E10 pig embryos (Gao et al. 2011).

Sexual dimorphism at the epigenetic level is directly bound to the appearance of sex-specific epigeneticbased phenotypes. An example of sex-biased epigenetic alteration is Beckwith-Wiedemann syndrome, a human epigenetic disorder to which the so-called 'Large Offspring Syndrome' in animals is considered equivalent 
(Farin et al. 2004). This syndrome is caused by altered methylation patterns at imprinting domains; it occurs at a relatively high frequency in monozygotic twins, and in almost all cases, the affected twins are female (Lubinsky \& Hall 1991, Weksberg et al. 2002). External stressors acting during the periconceptional period have also been reported to exert a sex-specific effect. In sheep, a methyl-deficient maternal diet during the periconceptional period leads to epigenetic alterations, which are more pronounced in males than in females (Sinclair et al. 2007). In rats, a restriction of dietary protein supplementation during the periconceptional period results in sex-specific cardiovascular and behavioral diseases in the offspring (Kwong et al. 2000, Watkins et al. 2008b), with females being more susceptible (Fleming et al. 2015b). The effect of this low-protein diet was mediated through changes in branched-chain amino acids and insulin levels in the uterine fluid, which were detected by embryos via the mTOR signaling pathway. These embryos were able to activate compensatory mechanisms in order to enhance maternal nutrient retrieval, by stimulating trophectoderm and primitive endoderm proliferation, endocytosis and cellular motility (Eckert et al. 2012, Sun et al. 2014, 2015). Although these responses protected foetal growth, at the same time, they led to abnormal growth and increased adult adiposity, resulting in adverse long-term effects, with female offspring more severely affected. Moreover, these effects were observed even when the embryos were transferred to mothers on a normal nutritional regime (Watkins et al. 2008a, 2010, 2011). Consistent with these studies, other authors have reported a greater response to stress by the female placenta compared to the male placenta in terms of gene expression (Clifton 2010, Osei-Kumah et al. 2011).

\section{Sex-specific long-term effects mediated by assisted reproductive technologies}

Assisted reproductive technologies may constitute an environmental stressor to the preimplantation embryo. Several studies reporting long-term consequences of in vitro culture or other ART identified a sex bias in the frequency and nature of the long-term effect (FernandezGonzalez et al. 2004, Sjoblom et al. 2005, Feuer \& Rinaudo 2012, Tarin et al. 2014). These deleterious effects have pointed to epigenetic alterations produced by ARTs. A number of reports have demonstrated that in vitro culture conditions induce alterations and errors in the epigenetic reprogramming of bovine embryos, leading to alterations in their DNA methylation pattern (Fernandez-Gonzalez et al. 2004, Niemann et al. 2010, Salilew-Wondim et al. 2015). Studies in mice have demonstrated that genomic imprinting in preimplantation embryos can be disturbed by specific culture conditions (Doherty et al. 2000, Khosla et al. 2001). Furthermore, mouse embryos cultured to the blastocyst stage using commercially available sequential media have been shown to suffer a shift in the expression of some nonimprinted genes (Morgan et al. 2008). Recently, we have shown that the presence of oviductal fluid within the culture medium during in vitro culture of bovine embryos provoked alterations of the methylation level of regions CpG in the developmental genes MTERF2, ABCA7 and OLFM1 and in the retrotransposon LINE-1 at the blastocyst stage when compared to control conditions using conventional culture medium supplemented with BSA (Barrera et al. 2017). Others have also shown that the methylation levels of the embryonic epigenome are affected by culture conditions in a developmental stagedependent manner (Salilew-Wondim et al. 2015). These epigenetic alterations, especially those provoked under suboptimal in vitro culture conditions, have been blamed as the cause of diverse disorders in the offspring, such as the 'Large Offspring Syndrome' in cattle and sheep (Chen et al. 2013). This condition is characterized by a disproportionate growth and reduced viability of the foetus. Similar effects are observed when mouse embryos are cultured in vitro with serum, but only in females, together with sex-dependent behavioral abnormalities (Fernandez-Gonzalez et al. 2004). However, in a similar model in mice, increased body weight and decreased brain size were only observed in males when they were cultured in the presence or absence of a specific growth factor, granulocyte-macrophage colony-stimulating factor, also known as colony-stimulating factor 2 (CSF2) (Sjoblom et al. 2005). CSF2 is a cytokine produced in the oviduct and endometrium that has been implicated in developmental programming (Giacomini et al. 1995, de Moraes et al. 1999, O'Leary et al. 2004, Nahar \& Kadokawa 2016) and its expression is modified by environmental factors. For example, seminal plasma triggers CSF2 expression (Tremellen et al. 1998, O'Leary et al. 2004, Bromfield et al. 2014), while maternal obesity can suppress it (Nahar \& Kadokawa 2016). In cattle, treatment with CSF2 from Day 5 to Day 7 after fertilization improved blastocyst development for female but not for male embryos. Furthermore, this treatment decreased embryo elongation and intrauterine accumulation of IFNT in females and affected the transcriptome and methylome in a different way for males and females (Siqueira \& Hansen 2016).

Metabolic alterations in the offspring associated with ARTs are also dependent on sex according to different studies. In mice, long-term effects associated with in vitro fertilization (IVF), intracytoplasmic sperm injection (ICSI) and somatic cell nuclear transfer (SCNT) were found to be sex specific, with females showing altered glucose clearance, higher body weight and adiposity (Scott et al. 2010a). In agreement, another study reported sex-specific differences in sterol metabolism, redox state, mobilization and oxidation of fatty acids after IVF in murine offspring, with females being more predisposed to increased fat accumulation (Feuer et al. 2014). 
However, in another study in mice produced from IVF, altered postnatal growth and glucose intolerance were only observed in males (Donjacour et al. 2014). Additional sexual dimorphic patterns induced by IVF were reported by Tan and coworkers (Tan et al. 2016). In this study, female embryos were more susceptible to apoptosis during the preimplantation and mid-gestation stages. Later in gestation, both males and females showed reduced placental angiogenesis, but compensatory placental overgrowth was more evident in males. Finally, overgrowth was only observed in males after birth (Tan et al. 2016). Our group has also reported a large number of sex-dependent alterations after ICSI using fresh or frozen sperm, including behavioral alterations, higher body weight and organ size and increased tumor incidence in females (Fernandez-Gonzalez et al. 2008, Ramos-lbeas et al. 2014).

\section{Sex differences after implantation: another source for sex-specific long-term effects}

Once the embryo has been implanted and $\mathrm{XCl}$ has been accomplished, transcriptional sex differences driven by sex chromosome dosage are reduced, but not abolished (Wijchers et al. 2010), compared to preimplantation development. However, once the gonads develop, a new factor for sexual dimorphism arises: sex hormones. From an evolutionary point of view, sex differences in foetal survival is seen as a way to adjust the energy invested by parents in male vs female offspring to the postnatal environment faced by the offspring (Trivers \& Willard 1973, Koskela et al. 2009). According to the TriversWillard hypothesis, mothers with plentiful resources invest in the sex with a reproductive disadvantage while those mothers facing adverse environment preferentially produce offspring of the sex with a greater chance of reproductive success (Trivers \& Willard 1973). The dominant concept is that female and male foetuses have different growth strategies, leading to differential survival and pregnancy outcomes. Thus, by their greater sensitivity to the maternal environment, females would follow modest growth changes and therefore better adaptation to deleterious signals such as maternal asthma and a restricted or high-fat diet. In contrast, male foetuses show a more divergent growth curve and as consequence poor adaptation to adverse environment (Clifton 2010, Eriksson et al. 2010, Cox et al. 2013). Although multiple observations support this hypothesis, there is a lack of solid experimental data from animal models in the literature unequivocally proving that male growth and survival in the womb is more affected than that of females when the environment is perturbed. It has been reported that a high-fat diet provokes undermethylation only of female placentas in mice, which is indicative of an active response to this stressor (GallouKabani et al. 2010); this was confirmed by another study showing that female placenta was more responsive to nutritional perturbations by more significant changes in the placental transcriptome (Mao et al. 2010). In rats, this higher adaptation was also observed for the female placenta in contrast to its male counterpart in response to ethanol by decreasing the 11ß-hydroxysteroid dehydrogenase-2 activity (Wilcoxon et al. 2003). In addition, in humans, the female placenta responds to antenatal steroid administration by upregulating 11ß-hydroxysteroid dehydrogenase-2 (Stark et al. 2009). These observations suggest that male foetuses are less buffered than females against certain environmental insults. Thus, under various stressors, male foetuses exhibit higher late foetal mortality due to a greater in utero vulnerability (Eriksson et al. 2010), and their foetal growth is more affected than that of females (Sundrani et al. 2017) (Fig. 1).

\section{Placental response to environmental stress}

The placenta is a gestational interface between mother and foetus that controls foetal development and growth through the exchange of gases, nutrients and waste products and also in the production of pregnancyinduced hormones, growth factors and immune response. Thus, the adaptive properties of this organ are essential for foetal survival during specific stresses and seem to be the main reason for the sex differences associated with stress observed during early and later foetal stages, affecting adult life as well (Gabory et al. 2013). The reported higher protection of female offspring in utero (Wilcoxon et al. 2003, Vickers et al. 2011) could be due to inherent sex differences in the placenta making the female placenta more adaptive and plastic. The sex differences of the human placenta have been revealed at the transcriptomic level. Global transcriptomic analyses revealed that females possess more upregulated autosomal genes, including immuneregulating genes, than males (Sood et al. 2006). This may indicate that human female placentae respond better to potential infections. In contrast, analyses of isolated cells derived from human placentae revealed sex-dependent differences in four placental cell types: cytotrophoblasts, synctiotrophoblasts and arterial and venous endothelial cells. In these analyses, male placentae showed enrichment of signaling pathways reported to mediate graft vs host disease and other transcripts involved in immune function and inflammation (Cvitic et al. 2013). The authors suggested that male placentae may be forced to upregulate immune-associated transcripts in an attempt to counteract the response of the maternal immune system due to a reduced maternalfoetal compatibility compared to female placentae. It has also been suggested that the structural and functional differences may contribute to enhance male susceptibility to in utero environmental perturbations (Kalisch-Smith et al. 2016). The placenta of human males invades more deeply into the spiral arteries than 
female placenta. In contrast, the latter exhibits more effective placental surface differentiation (Alwasel et al. 2014). In the spiny mouse (Acomys cahirinus), the female placenta contains a larger labyrinth but smaller spongy region than that of the male, and genes related to glucose transport were found to be differentially expressed among sexes in the two placental regions (O'Connell et al. 2013a). Based on rodent literature, it has been suggested that perturbation during early placental development may have a greater impact on viability and growth of the female foetus while those occurring later in gestation may preferentially affect the male foetus (Kalisch-Smith et al. 2016).

\section{Placental response to maternal diet}

All these inherent differences between male and female placenta are likely behind the differential response to the maternal environment. The available literature demonstrates that environmental exposures can disrupt placental morphology, epigenetic regulation and gene expression in a sex-dependent manner (Tarrade et al. 2015). The placenta adapts to the maternal diet and metabolic status altering foetal nutrient supply. This is done in a different way in male and female placentae showing different profiles of energy metabolism including glycogen storage and metabolism throughout gestation (O'Connell et al. 2013b). Animal studies have observed transcriptional sex differences in placentae under different maternal dietary regimes. In mice, it has been found that a low-fat vs high-fat diet deregulates significantly more genes in female than in male placentae (Mao et al. 2010) mainly affecting cell signaling of immune cells and uptake and metabolism of amino acids. In contrast, the genes affected in male placenta were related to development and function of the vascular system as well as uptake and metabolism of glucose and fatty acids (Gabory et al. 2012). These differences in gene expression can be explained by changes in epigenetic regulation. Thus, female placentae were found to be hypomethylated in response to a highfat diet in mice (Gallou-Kabani et al. 2010, Gabory et al. 2012). In rats, high-fat and high-salt diets lowered placental size of males, increasing the expression of genes associated with metabolism and pro-inflammatory mediators, which has been related to future cardiometabolic disturbances (Reynolds et al. 2015). In rabbits, high-fat and high-cholesterol diets provoke higher accumulation of triacylglycerol in males while they upregulate genes of the lipid pathway in females (Tarrade et al. 2013). In non-human primates, nutritional restriction has been reported to suppress genes related to programmed cell death and enhance genes associated with cell proliferation in female placentae. In contrast, male placentae showed less responsiveness in terms of the number of affected genes and pertinent pathways (Cox et al. 2013). In humans, it has been reported that obese women show thicker and less efficient placentae showing significant alterations meant for adaptation only in the female placenta (Mandò et al. 2016).

\section{Placental response to maternal psychological stress}

In utero exposure to maternal psychological distress affects the function of the foetal hypothalamus-adrenalpituitary (HPA) axis, which has implications for the development of diverse foetal tissues (Cottrell \& Seckl 2009, Harris \& Seckl 2011). Although this response to stress could be physiological, high stress and prolonged levels of prenatal stress and cortisol exposure can produce negative effects on foetal development (Laplante et al. 2004, Davis \& Sandman 2010). In response to this signaling, differential sex-dependent responses have been reported in both human and animal studies at both normal and pathological distress levels (Sandman et al. 2013). In order to buffer the impact of maternal psychological stress, placentae express $11 \beta$ HSD2 that degrades cortisol to cortisone. Interestingly, the female placenta is more reactive than the male, and higher expression of $11 \beta-\mathrm{HSD} 2$ has been shown in female placenta exposed to glucocorticoid treatment than that of males (Stark et al. 2009). Treatments with glucocorticoids have been shown to induce other alterations such as increased placental oxidative stress, expression of pro-inflammatory cytokine and 5 alphareductase (Scott et al. 2009, Vu et al. 2009, Stark et al. 2011), showing a more pro-oxidative state in male placentae.

According to the hypothesis of DOHaD (Barker 2007), the glucocorticoids transmitted from mother to foetus during gestation could be exploited by the foetus to optimize development in preparation for survival and success after birth (Gluckman et al. 2009, Ellis \& Del Giudice 2014). However, it has been argued that while sex-specific foetal growth strategies result in greater adaptive flexibility for females in the short term, especially under maternal distress, it increases the long-term risk of developmental psychopathology. Thus, anxiety and depression are two examples of stressrelated psychopathology for which there are clear sex differences in presentation and prevalence (Altemus et al. 2014).

\section{Response to sex hormones and endocrine disruptors}

From the early stages of development, the foetus is very susceptible to steroid hormone exposure, which plays important roles in tissue and organ differentiation (Sundrani et al. 2017). Thus, androgens have a role not only in the maturation of the male foetus but also in the development of mammary gland and folliculogenesis in the female foetus. Changes in these hormones due to maternal distress or endocrine disruptors differentially affect male and female foetuses. Low levels of androgen 
affect the development of testes in male foetuses and ovaries and adrenal cortex in female foetuses (Abbott et al. 2006) and an excess provokes alteration in testicular development (Rojas-García et al. 2013) and induces masculine characteristics in female foetuses (Wolf et al. 2002), foetal growth retardation (Manikkam et al. 2004) and polycystic ovarian syndrome in adult life (Hogg et al. 2011). At the same level as the sex hormones, also affecting the overall development of the foetus, endocrine-disrupting chemicals (EDC) have been highlighted as the main effectors altering placental and foetal performance in a deleterious way. EDC has been shown to alter gene transcription, signaling pathways (Tan et al. 2013, Xu et al. 2015), DNA methylation patterns (Nahar et al. 2015), miRNAs (Avissar-Whiting et al. 2010) and placental structure (Tachibana et al. 2007). However, a sex-dependent placental response is still not strongly supported by the literature. Thus, the only evidence to date is the differential DNA methylation of AluYb8 in response to the xenoestrogen burden in human placentas as higher methylation in males and no response in females (Vilahur et al. 2014). Other studies have also suggested that EDC can affect imprinted genes in the placenta (Susiarjo et al. 2013, Shin et al. 2014), but sex differences were not explored. Further studies are thus essential in addressing this critical gap in our understanding of how environmental chemicals interact with sex to affect placental outcomes.

\section{Conclusions}

Exposure to environmental stressors during preimplantation and peri-implantation development occurring either in vivo, such as during maternal diet imbalance, or in vitro, due to ARTs, activates compensatory responses in the embryo. These responses are often sex specific, due to the marked sex differences in transcriptional profiles at these stages, and may lead to long-term consequences, given the relevant epigenetic changes occurring during these early stages of development. Later, during foetal development, sexspecific foetal and placental responses may determine sex-specific long-term consequences to the exposure of environmental stressors such as maternal diet, stress or the exposure to endocrine disruptors. The epigenetic marks induced by specific environmental factors need to be identified in order to improve our understanding of the ontology of chronic diseases in response to these environmental factors by taking into account that male and female embryos and fetuses respond differently to the same environmental insult. Advances in transcriptomic and epigenomic tools make it possible to uncover the epigenetic roots of chronic diseases and their link to environmental insults and sex.

\section{Declaration of interest}

The authors declare that there is no conflict of interest that could be perceived as prejudicing the impartiality of this review.

\section{Funding}

This work has been funded by the State Secretariat for Research, Development and Innovation of the Spanish Ministry of Economy, Industry and Competitiveness through the projects AGL2015-66145R, AGL2015-70140-R and AGL201458739-R. P Lonergan is supported by Science Foundation Ireland (13/IA/1983).

\section{References}

Abbott DH, Padmanabhan V \& Dumesic DA 2006 Contributions of androgen and estrogen to fetal programming of ovarian dysfunction. Reproductive Biology and Endocrinology 4 17. (https://doi. org/10.1186/1477-7827-4-17)

Altemus M, Sarvaiya N \& Neill Epperson C 2014 Sex differences in anxiety and depression clinical perspectives. Frontiers in Neuroendocrinology 35 320-330. (https://doi.org/10.1016/j.yfrne.2014.05.004)

Alwasel SH, Harrath AH, Aldahmash WM, Abotalib Z, Nyengaard JR, Osmond C, Dilworth MR, Al Omar SY, Jerah AA \& Barker DJP 2014 Sex differences in regional specialisation across the placental surface. Placenta 35 365-369. (https://doi.org/10.1016/j.placenta.2014.03.003)

Arias-Alvarez M, Bermejo-Alvarez P, Gutierrez-Adan A, Rizos D, Lorenzo PL \& Lonergan P 2011 Effect of leptin supplementation during in vitro oocyte maturation and embryo culture on bovine embryo development and gene expression patterns. Theriogenology 75 887-896. (https://doi.org/10.1016/j.theriogenology.2010.10.031)

Attig L, Gabory A \& Junien C 2010 Early nutrition and epigenetic programming: chasing shadows. Current Opinion in Clinical Nutrition and Metabolic Care 13 284-293. (https://doi.org/10.1097/ MCO.0b013e328338aa61)

Avissar-Whiting M, Veiga KR, Uhl KM, Maccani MA, Gagne LA, Moen EL \& Marsit CJ 2010 Bisphenol A exposure leads to specific microRNA alterations in placental cells. Reproductive Toxicology 29 401-406. (https://doi.org/10.1016/j.reprotox.2010.04.004)

Barker DJ 2007 The origins of the developmental origins theory. Journal of Internal Medicine $261412-417$. (https://doi.org/10.1111/j.13652796.2007.01809.x)

Barker DJ \& Osmond C 1986 Infant mortality, childhood nutrition, and ischaemic heart disease in England and Wales. Lancet 1 1077-1081. (https://doi.org/10.1016/S0140-6736(86)91340-1)

Barrera AD, Garcia EV, Hamdi M, Sanchez-Calabuig MJ, Lopez-Cardona AP, Balvis NF, Rizos D \& Gutierrez-Adan A 2017 Embryo culture in presence of oviductal fluid induces DNA methylation changes in bovine blastocysts. Reproduction 154 1-12. (https://doi.org/10.1530/REP-16-0651)

Bermejo-Alvarez P, Rizos D, Rath D, Lonergan P \& Gutierrez-Adan A 2008 Epigenetic differences between male and female bovine blastocysts produced in vitro. Physiological Genomics 32 264-272. (https://doi. org/10.1152/physiolgenomics.00234.2007)

Bermejo-Alvarez P, Rizos D, Rath D, Lonergan P \& Gutierrez-Adan A 2010 Sex determines the expression level of one third of the actively expressed genes in bovine blastocysts. PNAS 107 3394-3399. (https:// doi.org/10.1073/pnas.0913843107)

Bermejo-Alvarez P, Rizos D, Lonergan P \& Gutierrez-Adan A 2011a Transcriptional sexual dimorphism during preimplantation embryo development and its consequences for developmental competence and adult health and disease. Reproduction 141 563-570. (https://doi. org/10.1530/REP-10-0482)

Bermejo-Alvarez P, Rizos D, Lonergan P \& Gutierrez-Adan A 2011b Transcriptional sexual dimorphism in elongating bovine embryos: implications for $\mathrm{XCl}$ and sex determination genes. Reproduction 141 801-808. (https://doi.org/10.1530/REP-11-0006) 
Bermejo-Alvarez P, Ramos-Ibeas P \& Gutierrez-Adan A 2012a Solving the ' $X$ ' in embryos and stem cells. Stem Cells and Development 21 1215-1224. (https://doi.org/10.1089/scd.2011.0685)

Bermejo-Alvarez P, Roberts RM \& Rosenfeld CS 2012b Effect of glucose concentration during in vitro culture of mouse embryos on development to blastocyst, success of embryo transfer, and litter sex ratio. Molecular Reproduction and Development 79 329-336. (https://doi.org/10.1002/ mrd.22028)

Bromfield JJ, Schjenken JE, Chin PY, Care AS, Jasper MJ \& Robertson SA 2014 Maternal tract factors contribute to paternal seminal fluid impact on metabolic phenotype in offspring. PNAS 111 2200-2205. (https://doi. org/10.1073/pnas.1305609111)

Cagnone GL, Dufort I, Vigneault C \& Sirard MA 2011 Differential gene expression profile in bovine blastocysts resulting from hyperglycemia exposure during early cleavage stages. Biology of Reproduction 8650. (https://doi.org/10.1095/biolreprod.111.094391)

Clifton VL 2010 Review: Sex and the human placenta: mediating differential strategies of fetal growth and survival. Placenta 31 (Supplement) S33-S39. (https://doi.org/10.1016/j.placenta.2009.11.010)

Cottrell EC \& Seckl JR 2009 Prenatal stress, glucocorticoids and the programming of adult disease. Frontiers in Behavioral Neuroscience $\mathbf{3}$ 19. (https://doi.org/10.3389/neuro.08.019.2009)

Cox LA, Li C, Glenn JP, Lange K, Spradling KD, Nathanielsz PW \& Jansson T 2013 Expression of the placental transcriptome in maternal nutrient reduction in baboons is dependent on fetal sex. Journal of Nutrition 143 1698-1708. (https://doi.org/10.3945/jn.112.172148)

Cvitic S, Longtine MS, Hackl H, Wagner K, Nelson MD, Desoye G \& Hiden U 2013 The human placental sexome differs between trophoblast epithelium and villous vessel endothelium. PLOS ONE 8 e79233. (https:// doi.org/10.1371/journal.pone.0079233)

Chen Z, Robbins KM, Wells KD \& Rivera RM 2013 Large offspring syndrome: a bovine model for the human loss-of-imprinting overgrowth syndrome Beckwith-Wiedemann. Epigenetics 8 591-601. (https://doi. org/10.4161/epi.24655)

Dahl JA, Reiner AH, Klungland A, Wakayama T \& Collas P 2010 Histone H3 lysine 27 methylation asymmetry on developmentally-regulated promoters distinguish the first two lineages in mouse preimplantation embryos. PLOS ONE 5 e9150. (https://doi.org/10.1371/journal. pone.0009150)

Davis EP \& Sandman CA 2010 The timing of prenatal exposure to maternal cortisol and psychosocial stress is associated with human infant cognitive development. Child Development 81 131-148. (https://doi. org/10.1111/j.1467-8624.2009.01385.x)

de Frutos C, Lopez-Cardona AP, Fonseca Balvis N, Laguna-Barraza R, Rizos D, Gutierrez-Adan A \& Bermejo-Alvarez P 2016 Spermatozoa telomeres determine telomere length in early embryos and offspring. Reproduction 151 1-7. (https://doi.org/10.1530/REP-15-0375)

de Moraes AA, Paula-Lopes FF, Chegini N \& Hansen PJ 1999 Localization of granulocyte-macrophage colony-stimulating factor in the bovine reproductive tract. Journal of Reproductive Immunology 42 135-145. (https://doi.org/10.1016/s0165-0378(98)00075-8)

Dobbs KB, Gagne D, Fournier E, Dufort I, Robert C, Block J, Sirard MA, Bonilla L, Ealy AD, Loureiro B et al. 2014 Sexual dimorphism in developmental programming of the bovine preimplantation embryo caused by colony-stimulating factor 2. Biology of Reproduction 9180. (https://doi.org/10.1095/biolreprod.114.121087)

Doherty AS, Mann MR, Tremblay KD, Bartolomei MS \& Schultz RM 2000 Differential effects of culture on imprinted H19 expression in the preimplantation mouse embryo. Biology of Reproduction 62 1526-1535. (https://doi.org/10.1095/biolreprod62.6.1526)

Donjacour A, Liu X, Lin W, Simbulan R \& Rinaudo PF 2014 In vitro fertilization affects growth and glucose metabolism in a sex-specific manner in an outbred mouse model. Biology of Reproduction 9080. (https://doi.org/10.1095/biolreprod.113.113134)

Ebner T, Tritscher K, Mayer RB, Oppelt P, Duba HC, Maurer M, Schappacher-Tilp G, Petek E \& Shebl O 2016 Quantitative and qualitative trophectoderm grading allows for prediction of live birth and gender. Journal of Assisted Reproduction and Genetics 33 49-57. (https://doi.org/10.1007/s10815-015-0609-9)

Eckert JJ, Porter R, Watkins AJ, Burt E, Brooks S, Leese HJ, Humpherson PG, Cameron IT \& Fleming TP 2012 Metabolic induction and early responses of mouse blastocyst developmental programming following maternal low protein diet affecting life-long health. PLOS ONE 7 e52791. (https:// doi.org/10.1371/journal.pone.0052791)

Ellis BJ \& Del Giudice M 2014 Beyond allostatic load: rethinking the role of stress in regulating human development. Development and Psychopathology $26 \quad 1-20 . \quad$ (https://doi.org/10.1017/ S0954579413000849)

Eriksson JG, Kajantie E, Osmond C, Thornburg K \& Barker DJP 2010 Boys live dangerously in the womb. American Journal of Human Biology 22 330-335. (https://doi.org/10.1002/ajhb.20995)

Farin CE, Farin PW \& Piedrahita JA 2004 Development of fetuses from in vitro-produced and cloned bovine embryos. Journal of Animal Science 82 (E-Supplement) E53-E62. (https://doi.org/10.2527/2004.8213_ supplE53x)

Fernandez-Gonzalez R, Moreira P, Bilbao A, Jimenez A, Perez-Crespo $M$, Ramirez MA, Rodriguez De Fonseca F, Pintado B \& Gutierrez-Adan A 2004 Long-term effect of in vitro culture of mouse embryos with serum on mRNA expression of imprinting genes, development, and behavior. PNAS 101 5880-5885. (https://doi.org/10.1073/pnas.0308560101)

Fernandez-Gonzalez R, Moreira PN, Perez-Crespo M, Sanchez-Martin M, Ramirez MA, Pericuesta E, Bilbao A, Bermejo-Alvarez P, de Dios Hourcade J, de Fonseca FR et al. 2008 Long-term effects of mouse intracytoplasmic sperm injection with DNA-fragmented sperm on health and behavior of adult offspring. Biology of Reproduction 78 761-772. (https://doi.org/10.1095/biolreprod.107.065623)

Feuer S \& Rinaudo P 2012 Preimplantation stress and development. Birth Defects Research Part C: Embryo Today 96 299-314. (https://doi. org/10.1002/bdrc.21022)

Feuer SK, Donjacour A, Simbulan RK, Lin W, Liu X, Maltepe E \& Rinaudo PF 2014 Sexually dimorphic effect of in vitro fertilization (IVF) on adult mouse fat and liver metabolomes. Endocrinology 155 4554-4567. (https://doi.org/10.1210/en.2014-1465)

Fleming TP, Velazquez MA \& Eckert JJ 2015a Embryos, DOHaD and David Barker. Journal of Developmental Origins of Health and Disease $\mathbf{6}$ 377-383. (https://doi.org/10.1017/S2040174415001105)

Fleming TP, Watkins AJ, Sun C, Velazquez MA, Smyth NR \& Eckert JJ $2015 b$ Do little embryos make big decisions? How maternal dietary protein restriction can permanently change an embryo's potential, affecting adult health. Reproduction, Fertility, and Development 27 684-692. (https://doi.org/10.1071/RD14455)

Forde N, Maillo V, O'Gaora P, Simintiras CA, Sturmey RG, Ealy AD, Spencer TE, Gutierrez-Adan A, Rizos D \& Lonergan P 2016 Sexually dimorphic gene expression in bovine conceptuses at the initiation of implantation. Biology of Reproduction 95 92. (https://doi.org/10.1095/ biolreprod.116.139857)

Gabory A, Ferry L, Fajardy I, Jouneau L, Gothié JD, Vigé A, Fleur C, Mayeur S, C Gallou-Kabani, Gross MS et al. 2012 Maternal diets trigger sex-specific divergent trajectories of gene expression and epigenetic systems in mouse placenta. PLOS ONE 7 e47986. (https://doi. org/10.1371/journal.pone.0047986)

Gabory A, Roseboom TJ, Moore T, Moore LG \& Junien C 2013 Placental contribution to the origins of sexual dimorphism in health and diseases: sex chromosomes and epigenetics. Biology of Sex Differences 45. (https://doi.org/10.1186/2042-6410-4-5)

Gallou-Kabani C, Gabory A, Tost J, Karimi M, Mayeur S, Lesage J, Boudadi E, Gross MS, Taurelle J, Vigé A et al. 2010 Sex- and dietspecific changes of imprinted gene expression and DNA methylation in mouse placenta under a high-fat diet. PLOS ONE 5 e14398. (https:// doi,org/10.1371/journal.pone.0014398)

Gao Y, Hyttel P \& Hall VJ 2011 Dynamic changes in epigenetic marks and gene expression during porcine epiblast specification. Cell Reprogram 13 345-360. (https://doi.org/10.1089/cell.2010.0110)

Gebert C, Wrenzycki C, Herrmann D, Groger D, Thiel J, Reinhardt R, Lehrach H, Hajkova P, Lucas-Hahn A, Carnwath JW et al. 2009 DNA methylation in the IGF2 intragenic DMR is re-established in a sexspecific manner in bovine blastocysts after somatic cloning. Genomics 94 63-69. (https://doi.org/10.1016/j.ygeno.2009.03.004)

Ghys E, Dallemagne M, De Troy D, Sauvegarde C, Errachid A \& Donnay I 2016 Female bovine blastocysts are more prone to apoptosis than male ones. Theriogenology 85 591-600. (https://doi.org/10.1016/j. theriogenology.2015.09.050)

Giacomini G, Tabibzadeh SS, Satyaswaroop PG, Bonsi L, Vitale L, Bagnara GP, Strippoli P \& Jasonni VM 1995 Epithelial cells are the 
major source of biologically active granulocyte macrophage colonystimulating factor in human endometrium. Human Reproduction 10 3259-3263. (https://doi.org/10.1093/oxfordjournals.humrep.a135899)

Gluckman PD, Hanson MA, Bateson P, Beedle AS, Law CM, Bhutta ZA, Anokhin KV, Bougnères $P$, Chandak GR, Dasgupta $P$ et al. 2009 Towards a new developmental synthesis: adaptive developmental plasticity and human disease. Lancet 373 1654-1657. (https://doi.org/10.1016/S01406736(09)60234-8)

Gomez E, Munoz M, Simo C, Ibanez C, Carrocera S, Martin-Gonzalez D \& Cifuentes A 2016 Non-invasive metabolomics for improved determination of embryonic sex markers in chemically defined culture medium. Journal of Chromatography A 1474 138-144. (https://doi. org/10.1016/j.chroma.2016.10.080)

Gutierrez-Adan A, Oter M, Martinez-Madrid B, Pintado B \& DeLa Fuente J 2000 Differential expression of two genes located on the $\mathrm{X}$ chromosome between male and female in vitro-produced bovine embryos at the blastocyst stage. Molecular Reproduction and Development 55146 151. (https://doi.org/10.1002/(SICI)1098-2795(200002)55:2<146::AIDMRD3>3.0.CO;2-F

Gutierrez-Adan A, Granados J, Pintado B \& De La Fuente J 2001 Influence of glucose on the sex ratio of bovine IVM/IVF embryos cultured in vitro. Reproduction, Fertility, and Development 13 361-365. (https://doi. org/10.1071/RD00039)

Gutierrez-Adan A, Perez-Crespo M, Fernandez-Gonzalez R, Ramirez MA, Moreira P, Pintado B, Lonergan P \& Rizos D 2006 Developmenta consequences of sexual dimorphism during pre-implantation embryonic development. Reproduction in Domestic Animals 41 (Supplement 2) 54-62. (https://doi.org/10.1111/j.1439-0531.2006.00769.x)

Harris A \& Seckl J 2011 Glucocorticoids, prenatal stress and the programming of disease. Hormones and Behavior 59 279-289. (https:// doi.org/10.1016/j.yhbeh.2010.06.007)

Heijmans BT, Tobi EW, Lumey LH \& Slagboom PE 2009 The epigenome: archive of the prenatal environment. Epigenetics 4 526-531. (https://doi. org/10.4161/epi.4.8.10265)

Hogg K, McNeilly AS \& Duncan WC 2011 Prenatal androgen exposure leads to alterations in gene and protein expression in the ovine feta ovary. Endocrinology 152 2048-2059. (https://doi.org/10.1210/en.20101219)

Hwang JY, Oh JN, Park CH, Lee DK \& Lee CK 2015 Dosage compensation of X-chromosome inactivation center-linked genes in porcine preimplantation embryos: non-chromosome-wide initiation of X-chromosome inactivation in blastocysts. Mechanisms of Development 138 246-255. (https://doi.org/10.1016/j.mod.2015.10.005)

Itoh Y \& Arnold AP 2014 X chromosome regulation of autosomal gene expression in bovine blastocysts. Chromosoma 123 481-489. (https:// doi.org/10.1007/s00412-014-0461-1)

Jimenez A, Madrid-Bury N, Fernandez R, Perez-Garnelo S, Moreira P, Pintado B, de la Fuente J \& Gutierrez-Adan A 2003 Hyperglycemiainduced apoptosis affects sex ratio of bovine and murine preimplantation embryos. Molecular Reproduction and Development 65 180-187. (https://doi.org/10.1002/mrd.10286)

Junien C, Gabory A \& Attig L 2012 Sexual dimorphism in the XXI(st) century. Medical Sciences 28 185-192. (https://doi.org/10.1051/ medsci/2012282017)

Kalisch-Smith JI, Simmons DG, Dickinson H \& Moritz KM 2016 Review: Sexual dimorphism in the formation, function and adaptation of the placenta. Placenta 54 10-16. (https://doi.org/10.1016/j. placenta.2016.12.008)

Kalisch-Smith JI, Simmons DG, Pantaleon M \& Moritz KM 2017 Sex differences in rat placental development: from pre-implantation to late gestation. Biology of Sex Differences 8 17. (https://doi.org/10.1186/ s13293-017-0138-6)

Kay GF, Barton SC, Surani MA \& Rastan S 1994 Imprinting and X chromosome counting mechanisms determine Xist expression in early mouse development. Cell 77 639-650. (https://doi.org/10.1016/0092 8674(94)90049-3)

Khosla S, Dean W, Brown D, Reik W \& Feil R 2001 Culture of preimplantation mouse embryos affects fetal development and the expression of imprinted genes. Biology of Reproduction 64 918-926. (https://doi.org/10.1095/biolreprod64.3.918)

Kobayashi S, Isotani A, Mise N, Yamamoto M, Fujihara Y, Kaseda K, Nakanishi T, Ikawa M, Hamada H, Abe K et al. 2006 Comparison of gene expression in male and female mouse blastocysts revealed imprinting of the X-linked gene, Rhox5/Pem, at preimplantation stages. Current Biology 16 166-172. (https://doi.org/10.1016/j.cub.2005.11.071)

Koskela E, Mappes T, Niskanen T \& Rutkowska J 2009 Maternal investment in relation to sex ratio and offspring number in a small mammal - a case for Trivers and Willard theory? Journal of Animal Ecology 78 1007-1014. (https://doi.org/10.1111/j.1365-2656.2009.01574.x)

Kwong WY, Wild AE, Roberts P, Willis AC \& Fleming TP 2000 Maternal undernutrition during the preimplantation period of rat development causes blastocyst abnormalities and programming of postnatal hypertension. Development 127 4195-4202.

Laguna-Barraza R, Bermejo-Alvarez P, Ramos-Ibeas P, de Frutos C, LopezCardona AP, Calle A, Fernandez-Gonzalez R, Pericuesta E, Ramirez MA \& Gutierrez-Adan A 2012 Sex-specific embryonic origin of postnatal phenotypic variability. Reproduction, Fertility, and Development 25 38-47. (https://doi.org/10.1071/RD12262)

Lamas-Toranzo I, Pericuesta E \& Bermejo-Alvarez P 2017 Memories of an X-chromosome. Stem Cell Investigation 4 27. (https://doi.org/10.21037/ sci.2017.03.01)

Laplante DP, Barr RG, Brunet A, Du Fort GG, Meaney ML, Saucier JFo, Zelazo PR \& King S 2004 Stress during pregnancy affects general intellectual and language functioning in human toddlers. Pediatric Research 56 400-410. (https://doi.org/10.1203/01. PDR.0000136281.34035.44)

Larson MA, Kimura K, Kubisch HM \& Roberts RM 2001 Sexual dimorphism among bovine embryos in their ability to make the transition to expanded blastocyst and in the expression of the signaling molecule IFN-tau. PNAS 98 9677-9682. (https://doi.org/10.1073/pnas.171305398)

Lowe R, Gemma C, Rakyan VK \& Holland ML 2015 Sexually dimorphic gene expression emerges with embryonic genome activation and is dynamic throughout development. BMC Genomics 16 295. (https://doi. org/10.1186/s12864-015-1506-4)

Lubinsky MS \& Hall JG 1991 Genomic imprinting, monozygous twinning, and X inactivation. Lancet 337 1288. (https://doi.org/10.1016/01406736(91)92956-3)

Mandò C, Calabrese S, Mazzocco MI, Novielli C, Anelli GM, Antonazzo P \& Cetin I 2016 Sex specific adaptations in placental biometry of overweight and obese women. Placenta 38 1-7. (https://doi. org/10.1016/j.placenta.2015.12.008)

Manikkam M, Crespi EJ, Doop DD, Herkimer C, Lee JS, Yu S, Brown MB, Foster DL \& Padmanabhan V 2004 Fetal programming: prenatal testosterone excess leads to fetal growth retardation and postnatal catch-up growth in sheep. Endocrinology 145 790-798. (https://doi. org/10.1210/en.2003-0478)

Mao J, Zhang X, Sieli PT, Falduto MT, Torres KE \& Rosenfeld CS 2010 Contrasting effects of different maternal diets on sexually dimorphic gene expression in the murine placenta. PNAS 107 5557-5562. (https:// doi.org/10.1073/pnas.1000440107)

Mendis S, Davis S \& Norrving B 2015 Organizational update: the world health organization global status report on noncommunicable diseases 2014; one more landmark step in the combat against stroke and vascular disease. Stroke 46 e121-e122. (https://doi.org/10.1161/ STROKEAHA.115.008097)

Morgan HD, Jin XL, Li A, Whitelaw E \& O'Neill C 2008 The culture of zygotes to the blastocyst stage changes the postnatal expression of an epigentically labile allele, agouti viable yellow, in mice. Biology of Reproduction 79 618-623. (https://doi.org/10.1095/ biolreprod.108.068213)

Morton KM, Herrmann D, Sieg B, Struckmann C, Maxwell WM, Rath D, Evans G, Lucas-Hahn A, Niemann H \& Wrenzycki C 2007 Altered mRNA expression patterns in bovine blastocysts after fertilisation in vitro using flow-cytometrically sex-sorted sperm. Molecular Reproduction and Development 74 931-940. (https://doi.org/10.1002/ mrd.20573)

Nahar A \& Kadokawa H 2016 Suppressed expression of macrophage migration inhibitory factor in the oviducts of lean and obese cows. Reproduction, Fertility, and Development 28 655-662. (https://doi. org/10.1071/RD14164)

Nahar MS, Liao C, Kannan K, Harris C \& Dolinoy DC 2015 In utero bisphenol A concentration, metabolism, and global DNA methylation across matched placenta, kidney, and liver in the human fetus. Chemosphere 124 54-60. (https://doi.org/10.1016/j.chemosphere.2014.10.071) 
Niemann H, Carnwath JW, Herrmann D, Wieczorek G, Lemme E, A Lucas-Hahn \& Olek S 2010 DNA methylation patterns reflect epigenetic reprogramming in bovine embryos. Cell Reprogram 12 33-42. (https://doi.org/10.1089/cell.2009.0063)

O'Connell BA, Moritz KM, Walker DW \& Dickinson H 2013a Sexually dimorphic placental development throughout gestation in the spiny mouse (Acomys cahirinus). Placenta 34 119-126. (https://doi. org/10.1016/j.placenta.2012.11.009)

O'Connell BA, Moritz KM, Walker DW \& Dickinson H 2013b Treatment of pregnant spiny mice at mid gestation with a synthetic glucocorticoid has sex-dependent effects on placental glycogen stores. Placenta 34 932-940. (https://doi.org/10.1016/j.placenta.2013.06.310)

O'Leary S, Jasper MJ, Warnes GM, Armstrong DT \& Robertson SA 2004 Seminal plasma regulates endometrial cytokine expression, leukocyte recruitment and embryo development in the pig. Reproduction 128 237-247. (https://doi.org/10.1530/rep.1.00160)

Okamoto I, Patrat C, Thepot D, Peynot N, Fauque P, Daniel N, Diabangouaya P, Wolf JP, Renard JP, Duranthon V et al. 2011 Eutherian mammals use diverse strategies to initiate $\mathrm{X}$-chromosome inactivation during development. Nature 472 370-374. (https://doi.org/10.1038/ nature09872)

Osei-Kumah A, Smith R, Jurisica I, Caniggia I \& Clifton VL 2011 Sexspecific differences in placental global gene expression in pregnancies complicated by asthma. Placenta 32 570-578. (https://doi.org/10.1016/j. placenta.2011.05.005)

Park CH, Jeong YH, Jeong YI, Lee SY, Jeong YW, Shin T, Kim NH, Jeung EB, Hyun SH, Lee CK et al. 2012 X-linked gene transcription patterns in female and male in vivo, in vitro and cloned porcine individual blastocysts. PLOS ONE 7 e51398. (https://doi.org/10.1371/journal. pone.0051398)

Perez-Crespo M, Ramirez MA, Fernandez-Gonzalez R, Rizos D, Lonergan P, Pintado B \& Gutierrez-Adan A 2005 Differential sensitivity of male and female mouse embryos to oxidative induced heat-stress is mediated by glucose-6-phosphate dehydrogenase gene expression. Molecular Reproduction and Development 72 502-510. (https://doi. org/10.1002/mrd.20366)

Petropoulos S, Edsgard D, Reinius B, Deng Q, Panula SP, Codeluppi S, Plaza Reyes A, Linnarsson S, Sandberg R \& Lanner F 2016 Singlecell RNA-Seq reveals lineage and $X$ chromosome dynamics in human preimplantation embryos. Cell 165 1012-1026. (https://doi. org/10.1016/j.cell.2016.03.023)

Ramos-lbeas P, Calle A, Fernandez-Gonzalez R, Laguna-Barraza R, Pericuesta E, Calero A, Ramirez MA \& Gutierrez-Adan A 2014 Intracytoplasmic sperm injection using DNA-fragmented sperm in mice negatively affects embryo-derived embryonic stem cells, reduces the fertility of male offspring and induces heritable changes in epialleles. PLOS ONE 9 e95625. (https://doi.org/10.1371/journal.pone.0095625)

Reynolds CM, Vickers MH, Harrison CJ, Segovia SA \& Gray C 2015 Maternal high fat and/or salt consumption induces sex-specific inflammatory and nutrient transport in the rat placenta. Physiological Reports 3 e12399-e12399. (https://doi.org/10.14814/phy2.12399)

Rojas-García PP, Recabarren MP, Sir-Petermann T, Rey R, Palma S, Carrasco A, Perez-Marin CC, Padmanabhan V \& Recabarren SE 2013 Altered testicular development as a consequence of increase number of sertoli cell in male lambs exposed prenatally to excess testosterone. Endocrine 43 705-713. (https://doi.org/10.1007/s12020-012-9818-5)

Salilew-Wondim D, Fournier E, Hoelker M, Saeed-Zidane M, Tholen E, Looft C, Neuhoff C, Besenfelder U, Havlicek V, Rings F et al. 2015 Genome-wide DNA methylation patterns of bovine blastocysts developed in vivo from embryos completed different stages of development in vitro. PLOS ONE 10 e0140467. (https://doi.org/10.1371/ journal.pone.0140467)

Sandman CA, Glynn LM \& Davis EP 2013 Is there a viabilityvulnerability tradeoff? Sex differences in fetal programming. Journal of Psychosomatic Research 75 327-335. (https://doi.org/10.1016/j. jpsychores.2013.07.009)

Scott NM, Hodyl NA, Murphy VE, Osei-Kumah A, Wyper H, Hodgson DM, Smith R \& Clifton VL 2009 Placental cytokine expression covaries with maternal asthma severity and fetal sex. Journal of Immunology 182 1411-1420. (https://doi.org/10.4049/jimmunol.182.3.1411)

Scott KA, Yamazaki Y, Yamamoto M, Lin Y, Melhorn SJ, Krause EG, Woods SC, Yanagimachi R, Sakai RR \& Tamashiro KL 2010 Glucose parameters are altered in mouse offspring produced by assisted reproductive technologies and somatic cell nuclear transfer. Biology of Reproduction $\mathbf{8 3}$ 220-227. (https://doi.org/10.1095/ biolreprod.109.082826)

Seisenberger S, Andrews S, Krueger F, Arand J, Walter J, Santos F, Popp C, Thienpont B, Dean W \& Reik W 2012 The dynamics of genome-wide DNA methylation reprogramming in mouse primordial germ cells. Molecular Cell 48 849-862. (https://doi.org/10.1016/j.molcel.2012.11.001)

Shin H-S, Seo J-H, Jeong S-H, Park S-W, Park Y, Son S-W, Kim JS \& Kang H-G 2014 Exposure of pregnant mice to chlorpyrifos-methyl alters embryonic $\mathrm{H} 19$ gene methylation patterns. Environmental Toxicology 29 926-935. (https://doi.org/10.1002/tox.21820)

Sinclair KD, Allegrucci C, Singh R, Gardner DS, Sebastian S, Bispham J, Thurston A, Huntley JF, Rees WD, Maloney CA et al. 2007 DNA methylation, insulin resistance, and blood pressure in offspring determined by maternal periconceptional B vitamin and methionine status. PNAS 104 19351-19356. (https://doi.org/10.1073/ pnas.0707258104)

Siqueira LG \& Hansen PJ 2016 Sex differences in response of the bovine embryo to colony-stimulating factor 2. Reproduction 152 645-654. (https://doi.org/10.1530/REP-16-0336)

Sjoblom C, Roberts CT, Wikland M \& Robertson SA 2005 Granulocytemacrophage colony-stimulating factor alleviates adverse consequences of embryo culture on fetal growth trajectory and placental morphogenesis. Endocrinology 146 2142-2153. (https://doi. org/10.1210/en.2004-1260)

Sood R, Zehnder JL, Druzin ML \& Brown PO 2006 Gene expression patterns in human placenta. PNAS 103 5478-5483. (https://doi. org/10.1073/pnas.0508035103)

Stark MJ, Wright IMR \& Clifton VL 2009 Sex-specific alterations in placental 11 beta-hydroxysteroid dehydrogenase 2 activity and early postnatal clinical course following antenatal betamethasone. American Journal of Physiology: Regulatory, Integrative and Comparative Physiology 297 R510-R514. (https://doi.org/10.1152/ajpregu.00175.2009)

Stark MJ, HodyI NA, Wright IMR \& Clifton VL 2011 Influence of sex and glucocorticoid exposure on preterm placental pro-oxidantantioxidant balance. Placenta 32 865-870. (https://doi.org/10.1016/j. placenta.2011.08.010)

Sturmey RG, Bermejo-Alvarez P, Gutierrez-Adan A, Rizos D, Leese HJ \& Lonergan P 2010 Amino acid metabolism of bovine blastocysts: a biomarker of sex and viability. Molecular Reproduction and Development 77 285-296. (https://doi.org/10.1002/mrd.21145)

Sun C, Velazquez MA, Marfy-Smith S, Sheth B, Cox A, Johnston DA, Smyth N \& Fleming TP 2014 Mouse early extra-embryonic lineages activate compensatory endocytosis in response to poor maternal nutrition. Development $\mathbf{1 4 1} 1140-1150 . \quad$ (https://doi.org/10.1242/ dev.103952)

Sun C, Denisenko O, Sheth B, Cox A, Lucas ES, Smyth NR \& Fleming TP 2015 Epigenetic regulation of histone modifications and Gata6 gene expression induced by maternal diet in mouse embryoid bodies in a model of developmental programming. BMC Developmental Biology 15 3. (https://doi.org/10.1186/s12861-015-0053-1)

Sundrani DP, Roy SS, Jadhav AT \& Joshi SR 2017 Sex-specific differences and developmental programming for diseases in later life. Reproduction, Fertility and Development.

Susiarjo M, Sasson I, Mesaros C \& Bartolomei MS 2013 Bisphenol a exposure disrupts genomic imprinting in the mouse. PLoS Genetics 9 e1003401. (https://doi.org/10.1371/journal.pgen.1003401)

Tachibana T, Wakimoto Y, Nakamuta N, Phichitraslip T, Wakitani S, Kusakabe K, Hondo E \& Kiso Y 2007 Effects of bisphenol A (BPA) on placentation and survival of the neonates in mice. Journal of Reproduction and Development 53 509-514. (https://doi.org/10.1262/ jrd.18171)

Tan W, Huang H, Wang Y, Wong TY, Wang CC \& Leung LK 2013 Bisphenol A differentially activates protein kinase $C$ isoforms in murine placental tissue. Toxicology and Applied Pharmacology 269 163-168. (https://doi. org/10.1016/j.taap.2013.03.016)

Tan K, Wang Z, Zhang Z, An L \& Tian J 2016 IVF affects embryonic development in a sex-biased manner in mice. Reproduction 151 443-453. (https://doi.org/10.1530/REP-15-0588)

Tarin JJ, Garcia-Perez MA, Hermenegildo C \& Cano A 2014 Changes in sex ratio from fertilization to birth in assisted-reproductive-treatment 
cycles. Reproductive Biology and Endocrinology 12 56. (https://doi. org/10.1186/1477-7827-12-56)

Tarrade A, Rousseau-Ralliard D, Aubrière M-C, Peynot N, Dahirel $M$, Bertrand-Michel J, Aguirre-Lavin T, Morel O, Beaujean N, Duranthon V et al. 2013 Sexual dimorphism of the feto-placental phenotype in response to a high fat and control maternal diets in a rabbit model. PLoS ONE 8 e83458. (https://doi.org/10.1371/journal.pone.0083458)

Tarrade A, Panchenko P, Junien C \& Gabory A 2015 Placental contribution to nutritional programming of health and diseases: epigenetics and sexual dimorphism. Journal of Experimental Biology 218 50-58. (https:// doi.org/10.1242/jeb.110320)

Taylor DM, Handyside AH, Ray PF, Dibb NJ, Winston RM \& Ao A 2001 Quantitative measurement of transcript levels throughout human preimplantation development: analysis of hypoxanthine phosphoribosyl transferase. Molecular Human Reproduction 7 147-154. (https://doi. org/10.1093/molehr/7.2.147)

Teh AL, Pan H, Chen L, Ong ML, Dogra S, Wong J, Mac Isaac)L, Mah SM, McEwen LM, Saw SM et al. 2014 The effect of genotype and in utero environment on interindividual variation in neonate DNA methylomes. Genome Research 24 1064-1074. (https://doi.org/10.1101/gr.171439.113)

Tremellen KP, Seamark RF \& Robertson SA 1998 Seminal transforming growth factor beta1 stimulates granulocyte-macrophage colonystimulating factor production and inflammatory cell recruitment in the murine uterus. Biology of Reproduction 58 1217-1225. (https://doi. org/10.1095/biolreprod58.5.1217)

Trivers RL \& Willard DE 1973 Natural selection of parental ability to vary the sex ratio of offspring. Science 179 90-92. (https://doi.org/10.1126/ science.179.4068.90)

Vickers MH, Clayton ZE, Yap C \& Sloboda DM 2011 Maternal fructose intake during pregnancy and lactation alters placental growth and leads to sex-specific changes in fetal and neonatal endocrine function. Endocrinology 152 1378-1387. (https://doi.org/10.1210/en.2010-1093)

Vilahur N, Bustamante M, Byun HM, Fernandez MF, Santa Marina L, Basterrechea M, Ballester F, Murcia M, Tardon A, Fernandez-Somoano A et al. 2014 Prenatal exposure to mixtures of xenoestrogens and repetitive element DNA methylation changes in human placenta. Environment International 71 81-87. (https://doi.org/10.1016/j.envint.2014.06.006)

Vu TT, Hirst JJ, Stark M, Wright IMR, Palliser HK, HodyI N \& Clifton VL 2009 Changes in human placental 5alpha-reductase isoenzyme expression with advancing gestation: effects of fetal sex and glucocorticoid exposure. Reproduction, Fertility, and Development $\mathbf{2 1}$ 599-607. (https://doi.org/10.1071/RD08224)

Watkins AJ, Ursell E, Panton R, Papenbrock T, Hollis L, Cunningham C, Wilkins A, Perry VH, Sheth B, Kwong WY et al. 2008a Adaptive responses by mouse early embryos to maternal diet protect fetal growth but predispose to adult onset disease. Biology of Reproduction $\mathbf{7 8}$ 299-306. (https://doi.org/10.1095/biolreprod.107.064220)

Watkins AJ, Wilkins A, Cunningham C, Perry VH, Seet MJ, Osmond C, Eckert JJ, Torrens C, Cagampang FR, Cleal J et al. 2008b Low protein diet fed exclusively during mouse oocyte maturation leads to behavioural and cardiovascular abnormalities in offspring. Journal of Physiology 586 2231-2244. (https://doi.org/10.1113/jphysiol.2007.149229)
Watkins AJ, Lucas ES, Torrens C, Cleal JK, Green L, Osmond C, Eckert JJ, Gray WP, Hanson MA \& Fleming TP 2010 Maternal low-protein diet during mouse pre-implantation development induces vascular dysfunction and altered renin-angiotensin-system homeostasis in the offspring. British Journal of Nutrition 103 1762-1770. (https://doi. org/10.1017/S0007114509993783)

Watkins AJ, Lucas ES, Wilkins A, Cagampang FR \& Fleming TP 2011 Maternal periconceptional and gestational low protein diet affects mouse offspring growth, cardiovascular and adipose phenotype at 1 year of age. PLOS ONE 6 e28745. (https://doi.org/10.1371/journal.pone.0028745)

Weksberg R, Shuman C, Caluseriu O, Smith AC, Fei YL, Nishikawa J, Stockley TL, Best L, Chitayat D, Olney A et al. 2002 Discordant KCNQ1OT1 imprinting in sets of monozygotic twins discordant for Beckwith-Wiedemann syndrome. Human Molecular Genetics 11 1317-1325. (https://doi.org/10.1093/hmg/11.11.1317)

Wijchers PJ, Yandim C, Panousopoulou E, Ahmad M, Harker N, Saveliev A, Burgoyne PS \& Festenstein R 2010 Sexual dimorphism in mammalian autosomal gene regulation is determined not only by Sry but by sex chromosome complement as well. Developmental Cell 19 477-484. (https://doi.org/10.1016/j.devcel.2010.08.005)

Wilcoxon JS, Schwartz J, Aird F \& Redei EE 2003 Sexually dimorphic effects of maternal alcohol intake and adrenalectomy on left ventricular hypertrophy in rat offspring. American Journal of Physiology: Endocrinology and Metabolism 285 E31-E39. (https://doi.org/10.1152/ ajpendo.00552.2002)

Wolf CJ, Hotchkiss A, Ostby JS, LeBlanc GA \& Gray LE 2002 Effects of prenatal testosterone propionate on the sexual development of male and female rats: a dose-response study. Toxicological Sciences 65 71-86. (https://doi.org/10.1093/toxsci/65.1.71)

Wrenzycki C, Lucas-Hahn A, Herrmann D, Lemme E, Korsawe K \& Niemann H 2002 In vitro production and nuclear transfer affect dosage compensation of the X-linked gene transcripts G6PD, PGK, and Xist in preimplantation bovine embryos. Biology of Reproduction 66 127-134. (https://doi.org/10.1095/biolreprod66.1.127)

Xu X, Chiung YM, Lu F, Qiu S, Ji M \& Huo X 2015 Associations of cadmium, bisphenol A and polychlorinated biphenyl co-exposure in utero with placental gene expression and neonatal outcomes. Reproductive Toxicology 52 62-70. (https://doi.org/10.1016/j.reprotox.2015.02.004)

Zvetkova I, Apedaile A, Ramsahoye B, Mermoud JE, Crompton LA, John R, Feil R \& Brockdorff N 2005 Global hypomethylation of the genome in XX embryonic stem cells. Nature Genetics 37 1274-1279. (https://doi. org/10.1038/ng1663)

Received 28 July 2017

First decision 28 September 2017

Revised manuscript received 9 October 2017

Accepted 12 October 2017 